\title{
The Promotion of Investment Alliances by the World Bank
}

\author{
Implications for National Health Policy
}

\author{
JANE LETHBRIDGE \\ Public Services International Research Unit (PSIRU), University of Greenwich, UK
}

\begin{abstract}
Aв STRACт This article will examine how World Bank policies that influence national healthcare systems have been facilitated through investment alliances between members of the World Bank Group, specifically the International Finance Corporation (IFC) and the Multilateral Investment Guarantee Agency (MIGA), regional development banks and multinational and national company interests. The data used in this article was gathered from the information and publications available through the websites of the World Bank Group, regional development banks, multinational companies and private equity investors. Some of the loan documents available through the websites of the World Bank Group and regional development banks were consulted. The financial complexity of many of the investments in new healthcare systems provides a challenge for future regulatory systems in healthcare. The involvement of a range of private sector interests in healthcare also poses problems for continued development of health knowledge within publicly funded systems.
\end{abstract}

KEYWORDS global health policy, investment alliances, privatization, World Bank

\section{Introduction}

This article examines how World Bank (http://www.worldbank.org) policies that influence national healthcare systems have been facilitated through investment alliances between members of the World Bank Group, 
specifically the International Finance Corporation (IFC; http://www.ifc.org) and the Multilateral Investment Guarantee Agency (MIGA; http://www. miga.org), regional development banks and multinational and national company interests.

The data used in this article was gathered from the information and publications available through the websites of the World Bank Group, regional development banks, multinational companies and private equity investors. Some of the loan documents available through the websites of the World Bank Group, including the IFC and the MIGA, and regional development banks were consulted. Research that explored the impact of broader capital account changes linked to World Bank and International Monetary Fund (IMF) policies was considered initially as a way of providing a context for more specific healthcare investments. Research examining the impact of health sector reforms over the past decade was used to develop a perspective on the changes taking place within healthcare systems.

Wade $(2001,2002)$ characterizes two major agendas operating within the World Bank: the 'finance ministry' agenda that promotes privatization, eliminates deficits, opens the economy and promotes foreign direct investment; and, the 'civil society' agenda that stresses poverty reduction and empowerment of poor people. Although both agendas agree on the need for health, education, environment and institutional development policies, the 'finance ministry' agenda is determined to protects its core elements e.g. privatization.

These agendas can also be characterized as the results of a more fundamental conflict between neoliberalism and state-led developmentalism. The pursuit of neoliberalism, often described as the belief in free movement of markets with little or no regulation, has resulted in the setting up of markets in areas which until recently were considered public services and so not subject to market systems. Public sector reform has been promoted as part of the change necessary to create quasi-market structures in areas such as healthcare and education, so that the private sector can become providers of services. The private sector will be either paid by government on behalf of health services users or directly by users themselves. These policies have come into conflict with welfare state systems and with national governments that are attempting to build some form of social protection for the majority of the population.

Strange (1994) and Leys (2001) both emphasize the role of multinational companies in national economies. Schneider and Tenbuecken (2002) point out that companies often get access to the policy-making process in exchange for cooperation in the implementation phase. In the field of healthcare, the role of private companies is only beginning to be understood. As many healthcare systems are still evolving towards a mix of public and private provision, there is still much to understand about how healthcare companies develop long-term relationships with governments. 
However, if the 'finance ministry' and 'civil society' agendas are seen as proxy indicators for the fundamental struggle between neoliberalism and welfare state development policies, they provide a useful framework for examining the process of transformation that is taking place in the healthcare systems of many developing countries and countries in transition. Some of the tensions that operate within the World Bank in relation to these two agendas can be illustrated by the case of healthcare investments and the World Bank Private Sector Development (PSD) Strategy. The process of developing the PSD Strategy provides further evidence of how World Bank policy is subject to pressure from both the 'finance ministry' agenda and the 'civil society' agenda although the extent to which 'civil society' can influence overall policy goals is probably limited.

\section{World Bank Policies}

The influence of the World Bank on national healthcare policies can be seen through World Development Reports (WDRs) relating to both healthcare and private sector development, and more specific healthcare strategies for parts of the World Bank Group. The annual WDR can be seen as a strong indication of World Bank policy. One of the most influential WDRs in relation to healthcare was 'Investing in Health' (World Bank, 1993), which presented strategies for providing cost-effective basic packages of public health and healthcare services. It argued that in order to deliver basic healthcare packages, the rest of the healthcare system would have to become self-financing. Extensive reforms and reallocation of public spending were needed to achieve this.

Governments were recommended to adopt user fees and self-financed insurance as well as investing in local level health centres and community care rather than more specialized care. Privatization of drug distribution, decentralization of healthcare management and more involvement of the private sector were also highlighted. Government regulation of insurance and the private sector were presented as an integral part of these reforms (World Bank, 1993). This report has influenced many government healthcare policies, which have often led to deterioration in the quality of services and level of accessibility rather than improvements in care (Afford, 2003; Bloom and Lucas, 1999; Bloom and Standing, 2001).

Although essential elements of public sector reform involve the promotion and development of the private sector to deliver public services, the process of outsourcing and contracting out of services has been slow in many developing countries (Polidano, 1999; Schacter 2000; Schick, 1998). The introduction of specific private sector development strategies in the late 1990s by multilateral financial institutions may be interpreted as an indicator of the lack of response of the existing private sector to the process of economic and 
public sector reform. It can also be seen as a response to the pressure to adopt strategies that reduce poverty and provide services for poor people.

The process of developing the World Bank PSD Strategy involved consultation with a range of stakeholders, including private sector, nongovernmental organizations (NGOs), trade unions, governments and regional development banks. An 'Issues and Options' (World Bank, 2001) paper was made available in June 2001 and this led to some form of dialogue with stakeholders worldwide. A draft version was made available in December 2001, with a final version approved by the Executive Directors in February 2002.

Bayliss and Hall (2002) analysed how the final version that was approved by the Executive Directors differed from the initial 'Issues and Options' paper. They found that there had been some changes made as a result of the consultation particularly in relation to the possibility of public provision of public services. One change in position was in relation to the failure of the private sector to take on the financial risks involved in delivering services, which had been the subject of criticism by a range of civil society organizations. Other issues that had been modified or at least showed some indication that other experiences had been considered covered competition and regulation. In relation to regulation, the new paper emphasized the need to regulate public and private sector providers which, while acknowledging the public sector, can still be interpreted as a subtle pro-privatization policy. Although the main aim of the strategy - to promote the development of the private sector - remained unchanged, it pointed out that 'Public provision of basic services is also a key component of developing a national-wide health or education system'.

The revised PSD strategy, launched by the World Bank in 2002, anticipates a wider role for the private sector in providing health and education services. The World Bank Group's Implementation Progress Report on PSD Strategy highlights its work so far in building up a private sector to deliver social services (World Bank, 2003a). There are signs that there has been extensive debate within the World Bank about how to promotion private provision in health and education.

However, the specific role of supporting private sector development in the healthcare sector is taken increasingly by the IFC, part of the World Bank Group, which describes itself as 'the largest multilateral source of loan and equity financing for private sector projects in the developing world' (accessed 1 February 2005, http://www.ifc.org). The IFC was set up to promote the flow of private capital from world money markets to developing countries, which helps to promote the development of a private sector in a specific industry (Lavelle, 1999). The IFC requires the support of state and non-state social coalitions in order operate effectively.

Although providing support for the development of a private sector, the IFC tries to complement private investors rather than supplant them, it also 
draws in additional funds from other sources and has to persuade investors to pursue the full commercial market risk in making investments. Unlike many international organizations, the IFC has a profit goal as well as a development goal. The work of the IFC complements the work of the World Bank in public sector reform, by focusing on the development of the private sector. The IFC is expected to increase its lending to private companies working in health in support of the World Bank PSD (Bijlmakers and Lindner, 2003).

Lavelle (1999) argues that over time, the IFC has changed from being the banker for developing countries to promoting funds where international investor interest is limited. In reality this means more IFC investments in poorer, riskier countries. In this sense, the IFC can be seen to be guided more by the 'finance ministry' than the 'civil society' agendas although the trend towards making IFC investments in poorer, more high risk countries, suggests that it too is also influenced by 'civil society' agendas.

Regional development banks were consulted as part of the PSD Strategy. Officially regional development banks describe their relationship with the World Bank Group as one of cooperation but there are also elements of competition between these regional players and multilateral financial institutions (Bull and Boas, 2003). Although the World Bank (2002) PSD Strategy has the highest profile, some of the regional development banks have developed their own private sector development strategies, often as a part of a poverty reduction strategy in the last few years (Asian Development Bank [ADB], 2000; Inter-American Development Bank [IADB], 2004).

\section{Policy Implementation}

An analysis of the healthcare investments that contribute to the development of financial infrastructure of the private healthcare sector, made by the IFC and the MIGA, both part of the World Bank Group, and regional development banks illustrates how healthcare reform programmes, privatization and private sector development strategies are beginning to intersect at international, regional and national levels. This article seeks to explore the hypothesis that multilateral agencies and regional development banks invest in the development of financial infrastructure for different forms of social protection, including healthcare, as part of a long-term strategy for the promotion of US-style social policies. The long-term implementation of USstyle social policies would be less effective without this specific financial infrastructure. Its development has a significant impact on the power of national governments to plan and control national healthcare systems.

Healthcare investments are often supported through several different types of investment alliances. The alliances developed by the IFC show how multinational companies and local companies are investing together in financial healthcare infrastructure projects. The relationships between the 
investment partners and the new companies being built up are focused on a shared set of financial interests that could lead to expanded business opportunities in future. For both multinational and local companies, shared investments in these new companies help to minimize the investment risk in a new enterprise.

Investment companies and financial institutions are also involved in IFC investments. The IFC remains a strong promoter of venture capital. Private equity and venture capital are playing an increasing role in providing investment for the global healthcare sector. Several US multinational healthcare companies have set up their own venture capital funds, for example, Humana Inc. (Summa Foundation, 2002; http://www.humana.com). These developments can be seen as another means of exporting US approaches to healthcare provision.

Several of the IFC investments are made in partnership with venture capital funds from global financial companies and independent venture capital trusts. Their relationship may be considered an investment alliance, which will help to yield a high rate of return rather than leading to future business opportunities in healthcare. In only one case has the private equity investor actually changed all its business interests into healthcare activities (http://www. oresaventures.com).

Several bilateral investment funds are partners in IFC projects. These alliances show how bilateral agencies are pursuing their own private sector development strategies. These strategies are not necessarily focused specifically on the development of private healthcare providers but on a wider private sector expansion.

The expansion of venture capital and private equity investments in the last decade can be seen as part of the expansion of the private sector worldwide. It can also be interpreted as the result of the over-accumulation of capital, which has led finance capital to search for new investment opportunities (Harvey, 2003). There is also a relationship between the creation of a new private healthcare sector and limiting funding for the public healthcare sector. The types of healthcare company receiving this financing are an indication of how the private healthcare sector will develop in future. There appears to be little interest in investing in the development of integrated primary health care or in developing preventive strategies.

At the moment there do not appear to be investment alliances set up between the IFC and any of the regional development banks in the field of healthcare. This may be related to different perspectives and understandings of health and social protection. However, one of the new IFC (2004) priorities is to develop stronger links with regional development banks so that this situation may change (http://www.ifc.org).

The investment alliances developed by regional development banks are more often focused on national partners. Government health ministries as well as private and non-governmental agencies have been drawn into invest- 
ТА В LE I International Finance Corporation (IFC) loans to private sector initiatives in the bealthcare sector

\begin{tabular}{|c|c|c|c|c|}
\hline Project & Details & IFC loan/total budget & $\begin{array}{l}\text { Multinational company } \\
(M N C) \text { involvement }\end{array}$ & National/ local investment \\
\hline $\begin{array}{l}\text { Innovative Health } \\
\text { Services (Brazil) }\end{array}$ & $\begin{array}{l}\text { Holding company which } \\
\text { supports companies developing } \\
\text { new healthcare services }\end{array}$ & US $\$ 6.5 \mathrm{~m} / \mathrm{US} \$ 25 \mathrm{~m}$ & $\begin{array}{l}\text { Jose de Mello Saude, } \\
\text { Portugal }\end{array}$ & $\begin{array}{l}\text { ICATU, Brazilian family- } \\
\text { owned conglomerate }\end{array}$ \\
\hline $\begin{array}{l}\text { MSF Funding LLC } \\
\text { (MSF) }\end{array}$ & Leasing medical equipment & $\begin{array}{l}\text { MIGA guarantee } \\
\text { US } \$ 90 \mathrm{~m}\end{array}$ & $\begin{array}{l}\text { DVI Inc. Philadelphia } \\
\text { International Equities }\end{array}$ & $\begin{array}{l}\text { Netherlands Development } \\
\text { Finance Company }\end{array}$ \\
\hline $\begin{array}{l}\text { Salutia (Argentina } \\
\text { and Brazil) }\end{array}$ & $\begin{array}{l}\text { E-health to provide solutions using } \\
\text { information communications } \\
\text { technologies to improve efficiency } \\
\text { and reduce management costs }\end{array}$ & US $\$ 2.5 \mathrm{~m} / \mathrm{US} \$ 12.5 \mathrm{~m}$ & $\begin{array}{l}\text { Merrill Lynch Global Emerging } \\
\text { Markets Partners, UBS Capital } \\
\text { and NAP Acquisition/ } \\
\text { Newbridge Latin America }\end{array}$ & 30 local investors \\
\hline $\begin{array}{l}\text { AAR Health Services } \\
\text { Limited, Kenya - } 1998\end{array}$ & $\begin{array}{l}\text { A managed healthcare } \\
\text { organization which aims to broaden } \\
\text { the shareholding and provide the } \\
\text { Company with credibility and } \\
\text { enhance AAR's ability to enter the } \\
\text { larger East African market }\end{array}$ & US\$0.5/US\$1.0m & $\begin{array}{l}\text { Acacia Fund, a managed fund of } \\
\text { Aureos Capital, one of two } \\
\text { managed funds for CDC Capital } \\
\text { Project Ventures Group (from } \\
\text { June 2004) }\end{array}$ & Beckmann family \\
\hline $\begin{array}{l}\text { Medicover (Central } \\
\text { and Eastern Europe) }\end{array}$ & $\begin{array}{l}\text { Provision of health insurance, health } \\
\text { services to companies and individ- } \\
\text { uals in Central/Eastern Europe }\end{array}$ & US $\$ 7 \mathrm{~m} / \mathrm{US} \$ 22 \mathrm{~m}$ & $\begin{array}{l}\text { ORESA Ventures, a venture } \\
\text { capital investor became Medicover }\end{array}$ & - \\
\hline $\begin{array}{l}\text { Ascent Technology } \\
\text { Fund }\end{array}$ & $\begin{array}{l}\text { To provide funds for medical } \\
\text { technology research in developing } \\
\text { countries }\end{array}$ & US $\$ 10 \mathrm{~m} / \mathrm{US} \$ 100 \mathrm{~m}$ & $\begin{array}{l}\text { Ascent Private Equity II, a private } \\
\text { US medical technology and } \\
\text { devices fund }\end{array}$ & - \\
\hline $\begin{array}{l}\text { Euromedic Diagnostics } \\
\text { BV and International } \\
\text { Dialysis Centres BV } \\
\text { (both subsidiaries of } \\
\text { Euromedic International) }\end{array}$ & $\begin{array}{l}\text { To expand the existing network of } \\
\text { Euromedic diagnostic imaging } \\
\text { centres in Hungary and other CEE } \\
\text { countries; and establish a network of } \\
\text { haemodialysis centres in the region }\end{array}$ & $\begin{array}{l}\text { US } \$ 13 \mathrm{~m} / \mathrm{US} \$ 33 \mathrm{~m} \\
\text { and US } \$ 11.4 / \\
\text { US } \$ 23 \mathrm{~m}\end{array}$ & $\begin{array}{l}\text { GE Equity Dresdner Keinwort } \\
\text { Benson Global Environment } \\
\text { Fund Euromedic International } \\
\text { NV }\end{array}$ & $\begin{array}{l}\text { HPM Partners - a privately } \\
\text { held Dutch investment } \\
\text { company }\end{array}$ \\
\hline $\begin{array}{l}\text { International Dialysis } \\
\text { Centres BV }\end{array}$ & $\begin{array}{l}\text { To set up an international dialysis } \\
\text { centre in Banja Luka, Bosnia }\end{array}$ & $\begin{array}{l}\text { MIGA US } \$ 1.3 \mathrm{~m} \\
\text { guarantee }(2001) \text { and } \\
€ 1.26 \mathrm{~m}(2004)\end{array}$ & & \\
\hline
\end{tabular}


ment alliances with regional development banks. For example, in Ecuador, the IADB (http://www.iadb.org) and Care Ecuador, a national branch of Care, a US non-governmental aid organization, are working together to test health franchising models through public-private partnerships in primary healthcare provision.

\section{INTERNATIONAL FINANCE CORPORATION}

Wade $(2001,2002)$, in a discussion of the hegemony of the World Bank, uses the term 'soft power' defined as 'the ability to make others want the same thing as yourself' (Wade, 2002: 217). This perspective is useful in trying to understand some of the investments made by the IFC and regional development banks in healthcare. Since 1997, the majority of IFC healthcare investments have been for the development of hospitals and clinics, which provide a specific physical infrastructure for the healthcare sector. There is also a second, smaller group of investments, concerned with the financing of healthcare and the use of information communications technologies, both contributing to a new form of healthcare development (Table 1). These investments are often characterized by the development of holding companies and other forms of financial infrastructure, which will be discussed. These are characteristics of a commercialized healthcare system illustrated most clearly by the USA. As some of these financial investments were made between 1997 and 2000, it is now possible to evaluate some of the short term 'successes' of these projects.

\section{HOLDING COMPANIES}

Although the majority of IFC healthcare projects in Latin America have been conventional investments in hospitals, there are several investments that have supported the setting up of companies which are contributing to new ways of organizing and financing healthcare systems, dominated by private sector providers. By investing in holding companies, these investments are effectively trying out new types of healthcare delivery and providing some of the management and information services that reformed health services require, which are all part of a commodified approach to healthcare delivery. The use of new information and communications technology is considered to have an important role to play in future healthcare services by making information about costing and payments easily available as well as providing health information for patients.

The example of Innovative Health Services, a Brazilian holding company, which received a loan of US\$6.25m loan from the IFC as part of a proposed capital budget of US\$25m in 1999, shows how within five years, this investment has resulted in the establishment of three new companies which deliver home healthcare, medical auditing and hospital management services. 'MedLar', the home healthcare services company has become one of the leading companies in Brazilian home healthcare. 'Gestal' provides management 
services for hospitals, which are experiencing falling sales and increased demand for quality services, a reflection of the changing position of many hospitals as a result of recent reforms. These two companies can be described as meeting the initial aim of the holding company, which was 'to provide support to new ventures and early stage development companies to improve the effectiveness and efficiency of the health care industry' (accessed 1 February 2005, http://www.ifc.org).

The investment alliance involved in this project brings together the IFC, a multinational company and a local company. Jose de Mello Saude (JMS; http://www.josedemello.pt), the healthcare division of the Portuguese Jose de Mello Group, which is active in several public-private healthcare projects in Portugal, owns 30\% of 'Innovative Health Services' (http://www.ihs.com.br). The Brazilian controlled ICATU group (http://www.icatu.com), one of the largest conglomerates in Brazil, also owns 30\%. This shows how both national and multinational healthcare companies are involved in investments that are expanding the private sector role in healthcare.

The significance of these types of private sector development in Brazil is threefold. The development of a homecare company shows that the delivery of care to people at home who are prepared to pay is considered to be profitable. Setting up companies that assess risk for life and health insurance companies puts an important part of the health insurance in place. The provision of management services for hospitals experiencing falling sales is an indication that the new markets in healthcare lead to both financial successes and failures. This is how market operating affects the provision of hospitals and healthcare. It is not determined by needs of local communities.

A more controversial holding company investment, started by the IFC but completed by the MIGA, illustrates how some hospital companies are changing the nature of their business interests from direct hospital management to the provision of finance for hospitals to lease equipment. National government investment companies and private investment companies are also becoming involved in this type of investment.

In 1999, MIGA issued a US\$90m guarantee for financing of a capital markets issue, providing international finance at lower interest rates to set up a holding company, MSF Funding LLC (MSF), for financing of medical equipment. MSF Holding was initially set up by IFC, forming a joint venture with DVI Inc. (a company financing leasing of medical equipment but previously owning hospitals) to form MSF Cayman, based in the Cayman Islands. DVI Inc. is a majority shareholder of MSF Holdings. The Netherlands Development Finance Company and Philadelphia International Equities are also shareholders, showing that both bilateral investment agencies and finance companies are involved in healthcare investment alliances. 
INFORMATION COMMUNICATIONS TECHNOLOGY

Information communications technology (ICT) also plays an important role in the new financial infrastructure of healthcare. The demand for this type of investment in healthcare seems not to have been affected by the collapse of Internet investments. The use of ICT in healthcare should be seen as part of an information infrastructure which private healthcare depends on to cost, price and collect payments for healthcare services. Information systems to support contract payments and check patient eligibility for care are also becoming important for public healthcare systems that operate as an internal market.

Some of these elements can be seen in an e-health company called Salutia that aims to apply new information communications technologies to healthcare. Set up in 1999, Salutia quickly attracted equity investors, such as Merrill Lynch, Newbridge and UBS Capital as well as the IFC to invest in technology, infrastructure and human resources. After surviving the economic crisis in Argentina, the company is now well established in Brazil. It describes itself as a company that 'provides solutions using technologies that improve efficiency and reduces management costs'. It works with many large healthcare companies as well as with over 500 smaller members in Argentina and Brazil. There has been a change in the image that it has presented on its website during the past three years. Starting as an Argentine company, which used the Internet to provide information for healthcare, it initially provided information for patients as well as developing services for healthcare companies. Three years later, it has developed a stronger Brazilian base and is now primarily working with companies.

This example shows that information communications technology investments play an important part in facilitating changes in the healthcare sector in order to accommodate private sector interests. These changes help to convert healthcare into a commodity that can be bought and sold. Companies can also adapt to changing economic and financial circumstances as seen in the way that Salutia changed its focus from the healthcare market in Argentina to the Brazilian market.

\section{HEALTH INSURANCE}

A further example of how the 'finance ministry' agenda has had to engage with the 'civil society' agenda can be seen in the World Bank model of public health systems providing basic services for low income groups, while promoting health insurance as a means for middle-class groups to pay for treatment from private health providers (Gwatkin, 2003; World Bank, 2003b). The IFC, in a recent health policy document, acknowledged that attempts to move people away from tax-based to insurance-based systems had had limited success in many countries (IFC, 2002). However, there is continuing pressure for middle-class groups in countries in transition and many developing countries to take out private health insurance in order to access private healthcare 
(Gwatkin, 2003). This is also recognized by multinational healthcare companies developing their activities in Asia (Lethbridge, 2004). One of the dangers of increased health insurance coverage is that companies prefer to insure healthy people who will use health services relatively infrequently. Eligibility criteria for people joining health insurance schemes will ensure that people with high health risks will either be excluded or pay larger premiums. This is known as 'cream skimming' and results in limited coverage of the population, often restricted to young adults. Older people may be excluded altogether from certain health insurance schemes.

The progress of health insurance companies in entering new markets has been an erratic one. One example of the limited success of US insurance companies can be seen in the case of Cigna which has entered and retreated from the Indian health insurance market because of the legal requirement for insurance companies to invest a minimum amount of capital. Even so, several IFC loans have been used to support the expansion of small health insurance companies. The process of developing a client base for new health insurance companies is a slow process. Some attempts have been made to link health insurance with healthcare providers by the same company, which is a form of managed care. Investment companies seem to be particularly interested in the expansion of health insurance.

Only one of the IFC investments in Africa over the past decade has been directly involved in the development of a health insurance company but the progress of this investment shows how finance capital is becoming involved in health insurance, albeit in a cautious way. AAR Health Services Limited, a managed care company operating in Kenya, received an IFC loan in 1998 to support its expansion into other East African countries. Six years later, in 2004, the company had gained a new shareholder: the Acacia Fund, one of the funds managed by CDC Capital (http://www.cdcgroup.com), the privatized investment arm of the UK government investment development company Commonwealth Development Corporation. This is another example of how national government investment companies are becoming involved in these type of healthcare investments. However, in May 2004, the company sold $35 \%$ of its shares to Project Ventures International, a company dealing with health and information technology in several counties in Africa. This has taken place at the same time as the Kenyan Government has proposed a new national health insurance scheme, which may affect private healthcare providers because companies will no longer have to provide healthcare insurance for their employees (Wandera and Njeru, 2004). This is significant in that it demonstrates that government policies can have a significant impact on private companies.

AAR is now planning to expand throughout Africa, using a franchise model of preventive and curative services. The franchise package entitles suitably qualified institutions to have access to an e-commerce-based computer software package, together with diagnostic, treatment, referral, laboratory, drug, 
customer care and accounting protocols. This package enables non-health companies to develop and deliver services themselves. Five franchise health centres have been set up in Tanzania, Uganda and Kenya.

\section{MEDICAL TECHNOLOGY}

Another form of technical infrastructure, which is becoming more important to the healthcare sector, is medical technology research and treatment, including the development of medical devices. Although this affects public and private healthcare sectors, private capital plays a key role in the expansion of research and the provision of equipment for diagnosis and treatment. The medical devices industry is part of a competitive global industry and it is a field of investment, which is considered to have the potential for high returns (Altenstetter, 2004). The value of high technology diagnosis and treatment is being recognized in the treatment of many diseases particularly noncommunicable diseases. For developing countries with limited healthcare systems, the focus on high technology equipment can result in the move of capital resources away from basic healthcare to more specialized services, which are only accessible to a minority of the population (Donaldson et al., 1999). Even when services are provided in public healthcare systems, they often result in a distortion of resources and services. High-technology equipment also needs a financial infrastructure to enable hospitals to borrow capital to buy or lease equipment.

Recent IFC investments reflect this trend towards high-technology treatments. Two East European investments show how private companies are building and leasing high-technology facilities to the public sector. In some cases, the initiatives attracted a wide range of investors. In others, particularly projects in countries with a recent history of war, investors need loan guarantees from MIGA because of the perceived element of risk involved.

Euromedic Diagnostics BV and International Dialysis Centers BV are both wholly owned subsidiaries of Euromedic International (http://www. euromedicgroup.com) a Netherlands based company. Euromedic is developing diagnostic centres with high-technology equipment to diagnosis and treat non-communicable diseases, e.g. renal care. Although established in five countries in Eastern and Central Europe, the IFC loan of US\$13m was to encourage further expansion of the national subsidiaries of Euromedic. A new loan was given by IFC for further expansion in 2003. Unlike many of the other IFC healthcare loans, this company works in partnership with the public sector. Euromedic invests in the diagnostic centres and the public healthcare system pays for the service based on contracts drawn up with National Insurance Institutes and supported by the Ministry of Health. It is now the largest investor in healthcare in Central and Eastern Europe.

In Bosnia, in a similar project, the MIGA, also part of the World Bank Group, is providing a guarantee of US $\$ 1.3 \mathrm{~m}$ for one of the same companies, International Dialysis Centers BV, to set up and manage an International 
Dialysis Centre in Banja Luka, which is being set up and managed within an existing hospital. A MIGA loan guarantee, rather than an IFC loan, is provided because of the perceived element of risk. The terms of the guarantee are to cover the risks of expropriation, war and civil disturbance. The European Union Investment Guarantee Fund is a second guarantor. This is an example of how private sector risks are being underwritten by IFC and the European Union (EU).

All of these investments need to be considered in the light of a recent review of IFC projects, which resulted in a slight change in IFC priorities. The new IFC healthcare strategy has identified several new growth areas 'with higher investment probability and where the rationale for IFC investment is strongest'. Three of these new growth areas cover the themes that have been identified through the analysis of IFC investments as just discussed: an increase in non-hospital investments; a stronger focus on private health insurance; and increased investments in the pharmaceutical, medical devices and biotechnology sub-sectors. The only new growth area, which does not appear in existing IFC investments, are investments in health worker education and training (IFC, 2004).

There is a further interesting development shown in the recently published IFC healthcare strategy, which relates to the tasks needed to implement the strategy (http://www.ifc.org). One of the most important seems to be the 'development of instruments to support small projects', for example, 'standalone out patient clinics or networks of clinics' (World Bank, 2003a). This reflects the view of both the World Bank and IFC that small private initiatives play an increasingly important role in the provision of healthcare. This is in contrast to the building of large hospitals, which characterized many of IFC's earlier loans. It also suggests that a different approach is being taken to building up the private healthcare sector, starting with small healthcare practitioners probably influenced by the poverty reduction strategies. The IFC also wants to work more with the non-governmental sector to help maximize social impact and poverty alleviation. However, it frames this in terms of ensuring 'more people have better financial protection against ill health, which in turn can strengthen the middle class' ('IFC Health Care Strategy Executive Summary', accessed 1 February 2005, http://www.ifc.org).

Other operational objectives that underpin the new IFC healthcare strategy include the development of stronger collaboration with multilateral and bilateral agencies as well as the non-governmental sector. In the next section, the healthcare investments of the African Development Bank (http://www.afdb. org), ADB (http://www.adb.org) and the IADB will show to what extent they are also building up financial healthcare infrastructure and how actively they collaborate with the IFC. 


\section{Regional Development Banks}

An examination of the policies and practice of regional development banks needs to start with the context of the specific regions within which they operate and the approach that regional development banks use in promoting social policy. Bull and Boas (2003) focused on the role of regional development banks and regionalism, and their work provides useful insights into how regional development banks differ. It also raises questions about how to define the relationships between multilateral financial institutions and regional development banks in relation to public sector reform and to what extent regional development banks are subject to the same pressures in terms of the 'finance ministry' and 'civil society' agendas.

Some indications of how regional banks respond to these pressures can be seen in the role that regional development banks play in regional integration. The ADB has supported a policy of sub-regional growth triangles, which can be seen as 'building blocks or foundations for a more all-embracing Southeast Asia regionalism' and the basis for a new security framework (Bull and Boas, 2003: 257). In contrast, the IADB has been able to play a role in some of the regional cooperation and integration processes that have taken place in Latin America through seeing them as technical issues and also 'filling regional projects with a specific content' (Bull and Boas, 2003: 257). Bull and Boas (2003) argue that the IADB has tried to present itself as an institution promoting a softer version of neoliberalism than the World Bank but it appears to be losing this struggle. It now appears as a strong promoter of neoliberal policies but it plays a specific role by providing technical expertise and support. Although there are broad similarities in health policies, a review of their health projects shows differences in implementation.

The ADB has provided loans for relatively few specific health projects and these are set within the framework of the ADB's social protection programme (Table 2). The amounts invested in either healthcare or social services are relatively small with most loans being less than US\$20m. Only Indonesia, in 1998 during the Asian economic crisis, received two larger loans of US\$300m for health, nutrition and social protection.

The loans of the ADB should also be seen in the context of East Asian development paths, which were shaped by the active role that the state played in national economic development (Castells, 1992; White and Wade, 1988). This has often been considered in direct conflict with World Bank views that emphasize the importance of the market. However Berger and Beeson (1998) argue that the World Bank has actually been responsible for changing the perception of East Asian development from being state focused to a more moderate form of market development. East Asian governments that still play an active role in economic development may also influence ADB strategies, leading to some divergence with the investment strategies of the World Bank.

Health sector reform is the focus of one or two loans but rural health, 
та в Lе 2 Asian Development Bank loans to private sector initiatives in the bealthcare sector

\begin{tabular}{|c|c|c|c|c|c|}
\hline Country & Programme & Details & Date & Amount & Partners \\
\hline Mongolia & $\begin{array}{l}\text { Health sector development - to help } \\
\text { Government implementation of health } \\
\text { system reforms and investment to improve } \\
\text { effectiveness, efficiency and sustainability } \\
\text { of health services }\end{array}$ & Policy reforms, investments and technical assistance & 1997 & US\$15.9 & - \\
\hline Vietnam & $\begin{array}{l}\text { Rural health - to provide primary and } \\
\text { preventive healthcare to the poor and dis- } \\
\text { advantaged, including ethnic minorities, } \\
\text { women and children, in the rural areas of } \\
13 \text { provinces of Viet Nam }\end{array}$ & $\begin{array}{l}\text { To improve access to health services by upgrading health } \\
\text { centres in rural areas. To enhance the skills of healthcare } \\
\text { service providers. To strengthen demand for health } \\
\text { services through targeted information, education and } \\
\text { communication activities, improved community } \\
\text { participation and more equitable health financing. To } \\
\text { support the Government's scheme to provide free health } \\
\text { cards to the poor. To support preventive healthcare } \\
\text { through strengthening of food safety infrastructure and } \\
\text { behaviour change communication }\end{array}$ & 2000 & US\$68.3m & $\begin{array}{l}\text { UNFPA, } \\
\text { UNICEF } \\
\text { WHO } \\
\text { co-financing } \\
\text { partners }\end{array}$ \\
\hline Philippines & $\begin{array}{l}\text { Early childhood development - to } \\
\text { develop, provide and promote an } \\
\text { integrated set of early childhood } \\
\text { development service delivery packages } \\
\text { to address the needs of children under six }\end{array}$ & $\begin{array}{l}\text { There are three components: (1) early childhood } \\
\text { development service delivery - programme support for } \\
\text { provinces and local government unit financing facilities } \\
\text { for municipal/city projects; (2) support for service } \\
\text { delivery; and (3) research and development }\end{array}$ & 1998 & US\$24.5 & \\
\hline Indonesia & $\begin{array}{l}\text { Health and nutrition sector development- } \\
\text { to help alleviate the impact of the economic } \\
\text { crisis on the most vulnerable groups and } \\
\text { building longer-term, sustainable reform } \\
\text { in health services delivery }\end{array}$ & $\begin{array}{l}\text { The policy reforms concentrate on four broad areas: } \\
\text { (1) maintaining access and equity (regional and socio- } \\
\text { cultural), especially for the poor; (2) maintaining quality; } \\
\text { (3) enhancing decentralized management; and } \\
\text { (4) improving efficiency }\end{array}$ & 1999 & US\$300 & \\
\hline $\begin{array}{l}\text { Central Asian } \\
\text { Republics }\end{array}$ & $\begin{array}{l}\text { Asian countries in transition for improved } \\
\text { nutrition for poor mothers and children }\end{array}$ & $\begin{array}{l}\text { To test an umbrella regional programme for delivering } \\
\text { micronutrient-fortified salt and wheat flour to the } \\
\text { populations of participating Asian Countries in Transition } \\
\text { (ACT), Azerbaijan, Kazakhstan, Kyrgyz Republic, } \\
\text { Mongolia, Tajikistan and Uzbekistan. }\end{array}$ & 2001 & US\$6.85 & \\
\hline $\begin{array}{l}\text { Greater } \\
\text { Mekong Delta }\end{array}$ & $\begin{array}{l}\text { Community action for preventing HIV/ } \\
\text { AIDS }\end{array}$ & $\begin{array}{l}\text { Strengthen capacities of the national and local HIV } \\
\text { authorities and selected NGOs for the development } \\
\text { of community-based prevention and care programmes }\end{array}$ & 2001 & US\$7.0 & \\
\hline
\end{tabular}

Source: http://www.adb.org 
nutrition and HIV/AIDS prevention projects have also been recipients of loans. However, within these broader health projects there are often some elements of health sector reform. The loan for the development of rural health in Vietnam includes strengthening 'the institutional capacity for public health care by coordinating and standardizing management systems, training programs and innovative financing approaches', which includes a pilot scheme to develop sustainable community health insurance (ADB, 2000).

In Africa, many of the health projects funded by the African Development Bank are directed towards building up the infrastructure of the public sector, e.g. hospitals and health centres, developing programmes for the prevention and treatment of HIV/AIDS, and other communicable diseases. In some cases, especially through the Poverty Reduction Strategy Papers (PRSP) the objectives are to improve basic social services, which are considered to include health, education, transport services and rural outreach services. The African Development Bank has invested in relatively few projects targeted specifically at the development of the private sector. Of these, a project for Senegal is designed to facilitate the creation of an enabling environment for the private sector but not specifically for the healthcare sector.

Many of the projects funded by ADB and the African Development Bank reflect the overall aims of improving the health of the population so that it can play a role in development. The projects funded by the IADB in Latin America show a different profile to those of the African and ADBs. It is also a contrast to the 1997 IADB health policy. Of almost 50 projects funded up to 2004 , over half were focused on health sector reform, supporting governments in programmes that cover regulation, management reform, strengthening the delivery system and the expansion of private or non-profit healthcare providers. There is also a sub-group of projects which are much more specifically targeted at the development of the private healthcare sector, funded by the Multilateral Investment Fund (MIF), a fund managed within the IADB.

The MIF, a part of the IADB Group, was created in 1993 'to encourage the development of the private sector and to improve the investment climate in the LAC region' (Grover and Lissfelt, 2000: 6). The current strategic priorities for MIF investments focus on four areas of activity: micro-enterprise, small business, financial sector and market functioning (IADB, 2004). The existence of MIF shows that IADB has a stronger policy focus on private sector development, specifically small-scale private sector development.

There are several approaches taken in the development of healthcare financial and organizational infrastructure by the MIF (Table 3). They illustrate the different elements of involving private healthcare providers in a wider public healthcare system and can be seen as part of national healthcare reform programmes. The promotion of new regulatory frameworks is considered a priority. This includes the development of new systems of regulation and helping local populations gain a better understanding of 
т А в L 3 Multilateral Investment Fund (MIF) projects in the healthcare sector

\begin{tabular}{|c|c|c|c|}
\hline Project name & Project description & Budget/date & Project partner(s) \\
\hline $\begin{array}{l}\text { Brazil } \\
\text { Regulation of } \\
\text { health plans }\end{array}$ & $\begin{array}{l}\text { To support a new regulatory framework for private health plans } \\
\text { to: enhance competition and efficiency in the private plan market; } \\
\text { strengthen consumer protection organization; instil new under- } \\
\text { standing and acceptance of new regulation in Brazilian society }\end{array}$ & $\begin{array}{l}\text { MIF US\$1,550,000 } \\
\text { Total US } 33,100,000 \\
2000\end{array}$ & $\begin{array}{l}\text { Secretary of State for } \\
\text { Economic Development } \\
\text { in Minas Gerais }\end{array}$ \\
\hline $\begin{array}{l}\text { Belize } \\
\text { Support for health } \\
\text { sector reform }\end{array}$ & $\begin{array}{l}\text { To create a policy, regulatory and purchasing environment for the } \\
\text { expansion of domestic private sector in publicly and privately } \\
\text { funded health services }\end{array}$ & $\begin{array}{l}\text { MIF US } \$ 771,650 \\
\text { Total US } \$ 1,228,790 \\
1999\end{array}$ & $\begin{array}{l}\text { Ministry of Health, Belize } \\
\text { Medical and Dental } \\
\text { Association }\end{array}$ \\
\hline $\begin{array}{l}\text { Colombia } \\
\text { Private enterprise } \\
\text { in subsidized } \\
\text { health programmes }\end{array}$ & $\begin{array}{l}\text { To encourage private enterprise to become involved in managing } \\
\text { healthcare delivery under the subsidized health plans }\end{array}$ & $\begin{array}{l}\text { MIF US } \$ 630,000 \\
\text { Total US } \$ 1,040,000 \\
1999\end{array}$ & Corona Foundation \\
\hline $\begin{array}{l}\text { Ecuador } \\
\text { Development of } \\
\text { health franchises }\end{array}$ & $\begin{array}{l}\text { To test reform financing models through public-private partner- } \\
\text { ships in the provision of healthcare and to improve the quality } \\
\text { and capacity of private sector provision of primary health services }\end{array}$ & $\begin{array}{l}\text { MIF US\$900,000 } \\
\text { Total US } \$ 1,550,000 \\
2000\end{array}$ & CARE Ecuador \\
\hline $\begin{array}{l}\text { Nicaragua } \\
\text { Strengthening of } \\
\text { private healthcare } \\
\text { services }\end{array}$ & $\begin{array}{l}\text { To support/promote private sector participation in the healthcare } \\
\text { services market by improving and broadening existing regulations } \\
\text { and creating an investment climate to support contracting. } \\
\text { This was cancelled in } 2002\end{array}$ & $\begin{array}{l}\text { MIF US\$1,710,000 } \\
\text { Total US } \$ 2,840,000 \\
2000\end{array}$ & Ministry of Health \\
\hline $\begin{array}{l}\text { Peru } \\
\text { Private sector health- } \\
\text { care providers }\end{array}$ & $\begin{array}{l}\text { To design and implement sharing health measurement information } \\
\text { systems, implement consumer protections systems and launch public } \\
\text { information campaign }\end{array}$ & $\begin{array}{l}\text { MIF US\$2,000,000 } \\
\text { Total US } \$ 3,400,000 \\
1998\end{array}$ & $\begin{array}{l}\text { Superintendencia de } \\
\text { Entidades de Prestadoras } \\
\text { de Salud - a public } \\
\text { decentralized agency that } \\
\text { regulates healthcare providers }\end{array}$ \\
\hline
\end{tabular}

Source: http://www.iadb.org 
regulation. The development of contracting skills within reformed healthcare systems is also presented as helping to involve private providers in a public healthcare system. Other means of drawing the private sector into the public healthcare system include promoting the franchising of primary healthcare centres, developing public-private partnerships and encouraging private companies to manage healthcare under subsidized health plans. These investments all focus on the new systems and processes that are necessary for mixed economy healthcare systems to operate.

The MIF provides up to two thirds funding for each project. Other funding comes from the project partners, which are nationally based organizations. They are more varied than in many of the IFC projects because they come from government, private or non-governmental agencies. There is no apparent direct involvement of multinational capital or investment companies.

Regional development banks seem to focus more on direct support for national health sector reform programmes. The IADB is the most specific investor in projects that will contribute to a financial infrastructure for the healthcare sector. The differences between regional development bank investments may also be a reflection of the different regional health problems and their specific healthcare needs. However, the private sector is also becoming a focus for future regional development bank investments. These differences may be interpreted as a sign of the pressure of the 'finance ministry' agenda even though civil society influences seem to be stronger within regional development banks than within the IFC. However, these regional differences may also be the result of differences in role that the state has played in national development.

A number of investments made by IFC, MIGA and three regional development banks aim to create new private companies that will provide healthcare services. A healthcare system based on a US social policy model, needs a financial infrastructure that facilitates the costing, pricing and sale of healthcare. Specific investments are needed to build up this type of financial infrastructure before new private sector companies will enter the market.

The ways in which IFC, MIGA and regional development banks are approaching these types of developments give some indication of how the often conflicting agendas of economic growth and empowerment and poverty reduction agendas are being mediated at international and regional levels. There are some differences, with regional development banks showing a greater awareness of the need for poverty reduction and responsiveness, perhaps because of their proximity to national and local interests.

\section{Implications for National Health Systems}

With increasing healthcare investments being made by private equity investors and multinational and national companies supported by the IFC, an 
expanding private sector will be eager to sell products that contribute to healthcare delivery. One of the key issues facing national healthcare systems is how national governments can control and regulate the private healthcare sector.

The health sector is already highly regulated. Personnel are regulated through qualifications and systems of professional registration. Service providers are regulated through the inspection of facilities. Contract systems also provide a way of regulating providers of services through shared agreements about delivery of services and costs. Recent research has shown that multinational healthcare companies agree that there is a need for regulation of personnel. They welcome common inspection systems because they provide a 'level playing field' for providers. However, multinational healthcare companies felt that regulation of ownership restricted their expansion most actively (Lethbridge, 2005). This is significant in searching for a stronger regulatory role for governments. If governments are felt to have a significant influence over multinational healthcare companies when limiting their patterns of ownership, then this should be explored in more depth by national governments.

Some of the investment alliances discussed in this article, which draw on several investment partners, contribute to obscuring the ownership of a healthcare company. This will make it difficult for any government to limit the involvement of any company in these types of investments. The Brazilian holding companies are an example of a financial structure that blurs the actual ownership of each new company. Several companies and investors are involved in every company, both national and international. In order to avoid this situation, national governments need to development systems of regulation that have very detailed guidance on acceptable ownership structures for providers of government services. This may require extensive research on the part of governments and a willingness to challenge existing investment alliances.

As well as making it difficult for governments to control, the complexity of the financial structure will also make any standards of transparency or accountability difficult to impose. This is particularly important in relation to private sector companies that are delivering services directly to the public healthcare sector. This is an important issue because governments are becoming dependent on private companies for the delivery of public healthcare services. If a company develops financial problems, the government needs to be aware of them. However, with unclear ownership structures, this may be difficult. A future system of government regulation will have to introduce minimum standards of information that all private providers of health services will have to comply with.

Another implication for future healthcare developments is in the growing role of companies in the healthcare sector that have little understanding of healthcare delivery. The franchise model illustrates some of the dangers of 
these arrangements because it encourages business interests to take on the provision of a service, defined as a series of systems and protocols, which can be adapted to any region or country by any company. This makes healthcare a more attractive short-term investment for a wider range of companies which do not necessarily have any healthcare knowledge to support them. This also contributes to the depletion of health knowledge in the public health system if franchised companies are providing services.

In the future, the extent of private sector involvement in public healthcare systems will almost certainly have expanded. Many companies are more interested in becoming direct providers for the public sector, because profits are more easily guaranteed than through a system of private health insurance. The increasing number of joint public-private initiatives will further increase the role of the private sector in the public healthcare sector. This provides a challenge for governments to develop new systems of planning and control, which serve the interests of the population rather than private sector interests.

REFERENCES

Afford, C.W. (2003) Failing Health Systems in Eastern Europe. Geneva and FerneyVoltaire, France: International Labour Office Socio Economic Security Programme and Public Services International.

Altenstetter, C. (2004) 'International Collaboration in Medical Device Regulation Issues, Problems and Stakeholders', paper presented at the UNRISD workshop Commercialization of Health Care: Global and Local Dynamics and Policy Responses', Helsinki, Finland, 15-17 March.

Asian Development Bank (ADB) (2000) News Release No. 120/00 9 (November), accessed 1 February 2005, http://www.adb.org

Bayliss, K. and Hall, D. (2002) 'Glimpses of an Alternative: The Possibilities of Public Ownership in the World Bank's Latest Private Sector Development Strategy', accessed 1 February 2005, http://www.psiru.org

Berger, M.T. and Beeson, M. (1998) 'Lineages of Liberalism and Miracles of Modernisation: The World Bank, the East Asian Trajectory and the International Development Debate', Third World Quarterly 19(3): 487-504.

Bijlmakers, L. and Lindner, M. (2003) The World Bank's Private Sector Development Strategy: Key Issues and Risks Executive Summary. An Leusden, The Netherlands: ETC Crystal and Wemos.

Bloom, G. and Lucas, H. (1999) 'Health and Poverty in Sub-Saharan Africa', Working Paper 103. Brighton: Institute of Development Studies, University of Sussex.

Bloom, G. and Standing, H. (2001) 'Pluralism and Marketisation in the Health Sector: Meeting Health Needs in Contexts of Social Change in Low and Middle Income Countries', Working Paper 136. Brighton: Institute of Development Studies, University of Sussex.

Bull, B. and Boas, M. (2003) 'Multilateral Development Banks as Regionalising Actors: The Asian Development Bank and the Inter-American Development Bank', New Political Economy 2: 245-61.

Castells, M. (1992) 'Four Asian Tigers with a Dragon Head: A Comparative Analysis of the State, Economic, and Society in the Asian Pacific Rim', in R.P. Appelbaum 
and J. Henderson (eds) States and Development in the Asian Pacific Rim (pp. 33-70). London: Sage.

Donaldson, D., Pannarunothai, P. and Tangcharoensathien, V. (1999) 'Health Financing in Thailand', Technical Report, Management Sciences for Health.

Grover, N. and Lissfelt, J. (2000) 'Labour Reform in Latin America and the Caribbean the Role of the Multilateral Investment Fund', Report for the Multilateral Investment Fund (MIF) of the Inter-American Development Bank. Bethesda, MD: QED Group LLC.

Gwatkin, D.R. (2003) Free Government Health Services: Are they the Best Way to Reach the Poor? Washington, DC: World Bank, accessed 1 February 2005, http://poverty.worldbank.org/library/view/13999

Harvey, D. (2003) The New Imperialism. Oxford: Oxford University Press.

Inter-American Development Bank (IADB) (2004) Private Sector Development Strategy. Washington, DC: IADB.

International Finance Corporation (IFC) (2002) 'Investing in Private Healthcare: Strategic Directions for IFC', paper presented at the World Bank/IFC Topical Briefing on Health and Investing in Private Healthcare, IFC, Washington, DC, March.

International Finance Corporation (IFC) (2004) 'Healthcare Strategy', accessed 1 February 2005, http://www.ifc.org

Lavelle, K.C. (1999) 'International Finance Institutions and Emerging Capital Markets in Africa', Review of International Political Economy 6(2): 200-24.

Lethbridge, J. (2004) 'Strategies of Multinational Healthcare Companies in Europe and South East Asia', paper presented at the UNRISD Workshop Commercialisation of Healthcare, Helsinki, 15-17 March.

Lethbridge, J. (2005, forthcoming) 'Strategies of Multinational Companies in Europe and Asia', in M. Mackintosh and M. Koivusalo (eds) Commercialization of Health Care: Global and Local Dynamics and Policy Responses. London: Palgrave Macmillan.

Leys, C. (2001) Market-Driven Politics, Neoliberal Democracy and the Public Interest. London: Verso.

Polidano, C. (1999) 'The New Public Management in Developing Countries', Public Policy and Management Working Paper 13, Institute of Development Policy Management, University of Manchester.

Schacter, M. (2000) 'Public Sector Reform in Developing Countries', Issues, Lessons and Future Directions Report. Ottawa: Policy Branch, Canadian International Development Agency.

Schneider, V. and Tenbuecken, M. (2002) 'Business and the State: Mapping the Theoretical Landscape', paper presented at the IPSA Business-Government Roundtable, School of Public Policy, University College, London, 24-5 May.

Schick, A. (1998) Principles of Public Expenditure Management. Washington, DC: World Bank.

Strange, S. (1994) States and Markets. London: Pinter Publishers.

Summa Foundation (2002) Financing for the Private Health Sector: A Tool to Assist the Private Health Sector in Developing Countries to Identify and Obtain Funding. Washington, DC: Summa Foundation for Commercial Market Strategies and the International Health Summit, funded by USAID.

Wade, R. (2001) 'Showdown at the World Bank', New Left Review (January-February) 7: 124-37.

Wade, R. (2002) 'US Hegemony and the World Bank: The Fight Over People and Ideas', Review of International Political Economy 9(2): 215-43. 
Wandera, N. and Njeru, K. (2004) 'Firm Acquires Shares in AAR', East Standard (22 May): 3.

White, G. and Wade, R. (1988) 'Developmental States and Markets in East Asia: An Introduction', in G. White (ed.) Developmental States in East Asia (pp. 1-29). London: Macmillan Press.

World Bank (1993) World Development Report: Investing in Health. Washington, DC: World Bank.

World Bank (2001) Private Sector Development Strategy: Issues and Options. A Discussion Document (1 June). Washington, DC: World Bank.

World Bank (2002) Private Sector Development Strategy: Directions for the World Bank Group (9 April). Washington, DC: World Bank.

World Bank (2003a) Implementation Progress Report Private Sector Development Strategy (20 June). Washington, DC: World Bank.

World Bank (2003b) Making Services Work for Poor People: World Development Report 2004. Washington, DC: World Bank.

RÉS U MÉ

\section{La Promotion d'alliances d'investissement par la Banque Mondiale: Implications pour les Politiques Nationales de Santé}

Dans cet article on examine comment les politiques de la Banque Mondiale qui influencent les systèmes nationaux de santé sont favorisées par des alliances d'investissement parmi les membres du Groupe de la Banque Mondiale, plus spécifiquement la Corporation financière internationale (IFC) et l'Agence Multilatérale de Garanties pour les Investissements (MIGA), les banques régionales de développement, et les intérêts des entreprises nationales et multinationales. Les données fournies dans cet article ont été obtenues des informations et publications disponibles sur les sites Internet du Groupe de la Banque Mondiale, les banques régionales de développement, des entreprises multinationales et des investisseurs privés. Nous avons aussi examiné quelques documents à propos de crédits disponibles sur les sites Internet du Groupe de la Banque Mondiale et des banques régionales de développement. La complexité financière de plusieurs investissements dans le domaine de nouveaux systèmes de soins de santé pose un défi pour les systèmes futurs de régulations de ces systèmes. La participation d'une vaste gamme d'intérêts privés dans les services de santé elle aussi pose des problèmes pour le developpement continu de connaissances sur la santé dans le cadre des systèmes avec financement publique.

RES UMEN

\section{La Promoción de Alianzas de Inversión por el Banco Mundial: Implicaciones para una Política Nacional de Salud}

Este artículo examina cómo las políticas del Banco Mundial que influyen en los sistemas nacionales de atención a la salud son facilitadas a través de alianzas de inversión entre integrantes del Grupo del Banco Mundial, específicamente la Corporación Financiera Internacional (IFC) y la Agencia Multilateral de Garantía de Inversiones (MIGA), los bancos regionales de desarrollo y los intereses de empresas 
multinacionales y nacionales. Los datos que se presentan en este artículo provienen de información y publicaciones disponibles en las páginas web del Grupo del Banco Mundial, los bancos regionales de desarrollo, empresas multinacionales e inversionistas privados. También se consultó algunos documentos sobre créditos disponibles en las páginas web del Grupo del Banco Mundial y los bancos regionales de desarrollo. La complejidad financiera de muchas de las inversiones en los nuevos sistemas de cuidado de la salud constituye un reto para los futuros sistemas regulatorios de la atención de la salud. La participación de una gama de intereses privados en la atención a la salud también presenta problemas para el desarrollo continuo de conocimientos sobre la salud en el marco de sistemas con financiamiento público.

BIOGRAPHICAL NOTE

Jane Lethibidge has been Senior Research Fellow at the Public Services International Research Unit (PSIRU), University of Greenwich since 2001. She has worked in the public and NGO sectors on UK and international public health issues. Her research interests are the global commercialization of health and social care, social dialogue and trade union action. Please address correspondence to: Jane Lethbridge, Senior Research Fellow, Public Services International Research Unit (PSIRU), Business School, University of Greenwich, Old Royal Naval College, Park Row, London SE10 9LS. [email: j.lethbridge@gre.ac.uk] 